\title{
Adoption Determinants of Improved Cook Stove Among Rural Households: The Case of Benishngul Gumuz Reginal State, Ethiopia
}

\author{
Gebrecherkos Asgele Bahta \\ Benshangul Gumuze Regional State Water Supply Bureau, Ethiopia \\ Weldeslasie Teklencheal Berhe \\ Ethiopian Civil Service University, Ethiopia
}

\begin{abstract}
Energy consumption of rural households' depends on traditional fuel sources including wood, crop residue, coal, and animal dung, which inefficient and largely attributed to air pollution and deforestation problems. To this end adoption of improved cook stove has anticipated to reduce these problems. So, the prime objective of the study was to investigate the determinants of improved cook stove adoption in Case of Assosa District, Benishngul Gumuz Reginal State, Ethiopia in the year 2018. The study was conducted based on descriptive design and mixed method research on a target population of 3880 households from Assosa district with sample size of 341 households that determined using Kothari formula based on proportional sampling technique from each selected sub districts and $20 \mathrm{key}$ informants selected using purposive sampling technique. Binary logit regression model was employed for econometrics analysis using STATA software. The finding showed that stove design and neighborhood effect are the most determinants of improved cook stove adoption. Hence, for fast dissemination; cook stove design should not be one fit for all policy rather cooks stove design should take into account the sociocultural feeding practice of the potential adopters.
\end{abstract}

Keywords: Adoption, improved cook stoves, Binary logit regression.

DOI: $10.7176 / \mathrm{JETP} / 10-3-03$

Publication date:July $31^{\text {st }} 2020$

\section{Introduction}

The open fires and primitive stoves have been used for cooking since the beginning of human history with various sizes and styles and have been modified based on cultures, food preparation approaches and stove models (Sameer, 2011). In developing countries about 3 billion people's energy sources is depend on traditional fuel including wood, charcoal, coal, leave, crop residues and animal dung with traditional and inefficient stove technology to meet household cooking and heating needs (World Bank, 2011).

In many countries women are responsible for the collection, transportation, processing and storing of fuel, as well as the cooking activities; burdens associated with traditional biomass cooking are disproportionally felt by women because of their customary involvement in cooking, women's exposure is much higher than Men's (Grace, 2014).

These open fire and traditional cook stove emit substantial amount of smoke which affects human health, high deforestation, negative impact of climate change and losses production opportunity (Puzzolo et al., 2013: Tsigie, 2014:Warkaw, 2015). According International Energy Agency (2010), estimated that about 1.5 million per year pre mature deaths are associated with the indoor air pollution in 2030, which more deaths than malaria. Ethiopia's energy supply is heavily depending on traditional solid fuel energy both in rural and urban areas that account about $95 \%$ (World Vision, 2016).

The government and concerned stakeholders have not give enough attention to the status of adopting improved cook stove. Improved cook stove is a device that designed to improve combustion efficiency of biomass, consume less fuel, save cooking time, convenient in cooking practice and creates smokeless environment in the kitchen and reduce the volume of smoke against the traditional stove (Damte and Koch, 2011).

\section{Problem Statement and Literature Review}

Ethiopia is one of the least developed countries, with the lowest per capita energy consumption and dominated by traditional sources of energy. About $95 \%$ of the total national energy consumption is derived from traditional biomass fuel; only $5 \%$ is derived from commercial energy mainly petroleum fuels and electricity (Woldu, 2015).

The extensive poverty in developing countries needs appropriate energy service provision to pull out of poverty which is vital input for socio economic growth, mainly for industries, commerce, agriculture, and social services that last longing best of sustained development. The first attempt to improve traditional solid biomass stoves was made in India in the 1950s which have been designed with a chimney to remove smoke from the kitchen (Hammond, 2007). In 1970s researchers was focused on the technical aspects biomass stoves like thermodynamic 
and heat transfer but the adoption of stoves still remain at marginal level (Puzzolo et al., 2013; and Gifford, 2010).

These traditional cook stoves have very low energy efficiency, most of the potential energy $85 \%$ or more is wasted comparing to improved cooking stoves and mostly causes of indoor and outdoor pollutions (Zenebe, 2007). The nature and concept of Improved cook are designed to improve energy efficiency, remove smoke from the indoor living space, or lessen the drudgery of cooking duties modified to suit the cooking traditions and type of food to be cooked (Hude, 2014). Improved cook stove optimized heat transfer, reduced fuel consumption and emissions, reducing health impacts and deforestation which in turn reduce climate impacts (Smith et al., 2014).

The strategy of the Ethiopian government is to reduce the demand on wood fuel, conserve the forest and militate against increase greenhouse gaze effect, and reduces indoor air pollution by introducing improved wood stove. But the current penetration level of improved efficient wood stove for the rural households is still below $23 \%$, that is the adoption of the technology has been slow and unevenly distributed among households which are unaware fully about the technology (Shanko, 2009).

According (Anthony and Chikamso, 20017), even the access to energy is gradually improving to reach $20 \%$ by the efforts of the government, but lower than the Sub-Saharan Africa average $26 \%$. As a result, the efficient energy supply coverage in the rural areas still remains low because of limited progress in modern energy supply activities. This major problem leads to biomass which covers 80-95\% Ethiopia's primary energy demand by inefficient way (Heimann, 2007: warkaw, 2015).

Unfortunately, studies about the determinant factors of improved cook stove adoption are limited in Ethiopia, studies by Gebreeziabher (2012) and Warkaw (2011) both in Tigray, Tigabu (2014) in Amhara and Amogne (2014) in Oromia; were based on what factors determine household demand for cook stove energy which are household characteristics, household income, stove price, having separate kitchen, access to open forest and social and institutional influence. But the determinants of improved cook stoves adoption and sustained use have not been yet fully examined and the supply side factors such as access to credit, suitable stove design, production site decentralization and early adopter neighbors are not include in identifying determinant factors of rural household improved cook stove adoption decision in previous studies.

Improved biomass energy technologies have the potential to reduce the negative impacts of traditional biomass energy use (Beyene and Koch, 2011). Improved cook stoves are designed to reduce heat loss, decrease indoor air pollution, increase combustion efficiency and attain a higher heat transfer (Masera et al., 2000).

Additionally, most of the previous studies also conducted on highland areas of Ethiopia in which where the feeding culture of the highlanders are different from the lowlands; the former familiar with 'injera' baking but the later(the study area) familiar with the unique mode of baking porridge (Genfo baking) which consumes more fire wood and time from water heating up to baking with open fire and inefficient way of cooking than 'injera' baking which leads high environmental, health and agricultural productivity effects. Therefore; the researcher concerned about the determinant factors of improved cook stove adoption of the households in the district as a result to fill the above gaps.

\section{Methodology}

Research methodology is the conceptual framework within which the research would be conducted. It is a road map that shows how all the major parts of the research study come together. It articulates and presents all essential methods which are helpful to meet the desired objectives of the study in efficient and effective manners.

Data Collection Methods: The unit of analysis of this study was the efficient cook stove adopters and non-adopter households in rural Assosa district from selected twelve sub districts. And both secondary and primary sources of data as well as cross sectional data type were employed over the selected rural households. And as part of the primary data collection key informant interview was also conducted.

Sampling Design: The target population of the district were comprised 74 sub districts out of which the researcher were select 12 sub districts by random sampling techniques. In addition 20 key informants such as technical staff experts (chief regional energy experts, core processor owners, district environment officer, energy officer, health officer), cook stove production artisans, users directly concerned with cook stove issues in the district which represent a cross section of the total population of Assosa district were employed.

Sampling techniques: Both probability and non - probability sampling technique procedures were used to select the survey areas and sampling unit of households selected and interviewees. At first stage, Assosa district were selected randomly from the Benishangul Gumuz regional state of 20 districts. In the second stage, the district classified in cluster based on the geographical and cultural characteristics of the community then next 12 sub district were selected from each cluster proportionally through random lottery method in order to accommodate 349 household. Similarly purposive sampling technique was employed to select key informant interviewees as all employs don't have equal information about the issue at hand.

Sampling Frame: The list of households from selected sub districts and the list of key informant interviewees from relevant offices and bureaus in the study area were the sample frames of the study. 
Sample Size Determination: Using Kothari (2004: pp. 179) sample size determination formula $\mathrm{n}=\frac{z^{2} p q}{e^{2}}$ with $95 \%$ level of confidence interval a total of $n=349$ rural households were randomly selected from the selected 12 sub districts of the study area out of the $\mathrm{N}=3880$. Each sub district has a sample size proportional to its population.

In addition using purposive non - probability sampling technique in order to get information from office and bureau employees and leaders because who haven't equal chance of selection to get main information from the key informants comprised of 20.

\section{Data Collection Instruments}

Questionnaire, Interview were used questionnaire to collect the primary data, to explore variables under investigation in a greater detail with the key informants as well as observation and photography observation was constantly made on particular interest like areas where improved cook stove adopters and traditional cook stove users, stove production sites were photographed.

\section{Methods of Data Processing and Analysis}

With the objective of reducing uncertainty, incomplete answers and other fictitious responses the STATA and SPSS software version 14 and 22 respectively. On the other hand data collected through semi-structured interviews were analyzed by the use of intensive textual analysis.

Data Analysis: To achieve the objectives of the study both descriptive and econometrics analysis was used. Descriptive statistics includes mean, standard deviation, frequency and percentile were computed for the variables following the completion of data processing, and also run a t-test for continuous variables and chi-square test for dummy variables to detect the statistically significant differences between households which adopt and that did not adopt improved cook stove.

\section{Operational Definitions and Description of Variables}

Dependent variable: cook stove adoption (csa) was given value ' 1 ' if the household adopters while ' 0 ' assigned to non-adaptors. To assess the status of cook stove adoption by rural households, respondents were asked whether they purchase cook stove in the form of yes or no questions.

Independent variable: The independent variables are selects based on the existing theories and empirical studies. Table 3.1. Operational Definition and Description of variables with expected result

\begin{tabular}{|c|c|c|}
\hline Variables & Operational Definition & Expected result \\
\hline Age (age): & it is a continuous variable measured in years & In determine $(+/-)$ \\
\hline Marital status (marsta) & $\begin{array}{l}\text { Marital status is a dummy which refers to respondent's states of being } \\
\text { single or married. A value of ' } 1 \text { ' will be given to married ' } 0 \text { ' for single. }\end{array}$ & $\begin{array}{l}\text { Negative } \\
(-)\end{array}$ \\
\hline $\begin{array}{l}\text { Education level hh head } \\
\text { (litle) }\end{array}$ & $\begin{array}{l}\text { Literacy level is a dummy which refers to whether the respondent is } \\
\text { literate (can read and write) or illiterate (cannot read and write). A value } \\
\text { of ' } 1 \text { ' will be assigned for literate and ' } 0 \text { ' for illiterate. }\end{array}$ & Positive $(+)$ \\
\hline Family size (famsize): & $\begin{array}{l}\text { it is a discrete variable, the number of family size live in the same } \\
\text { household. }\end{array}$ & In determine $(+/-)$ \\
\hline $\begin{array}{l}\text { Separate } \\
\text { (sepakich) }\end{array}$ & $\begin{array}{l}\text { It is about whether the household has separate kitchen or not. Separate } \\
\text { kitchen is a dummy valued ' } 1 \text { ' for house holed that has separate kitchen } \\
\text { and ' } 0 \text { ' for has not. }\end{array}$ & In determine $(+/-)$ \\
\hline $\begin{array}{l}\begin{array}{l}\text { Source } \\
\text { (sowood) }\end{array} \text { of wood } \\
\end{array}$ & $\begin{array}{l}\text { It is a dummy that refers to whether households get fuel-wood without } \\
\text { charge or with charge. A value of ' } 1 \text { ' for households that gets wood } \\
\text { without charge and ' } 0 \text { ' for with charge. }\end{array}$ & $\begin{array}{l}\text { Negative } \\
(-)\end{array}$ \\
\hline Price (price) & $\begin{array}{l}\text { It is a continues variable price refers to the end users cost to buy cook } \\
\text { stove in Ethiopia birr }\end{array}$ & \\
\hline $\begin{array}{l}\text { Distance from } \\
\text { production }\end{array}$ & $\begin{array}{l}\text { It is dummy that refers households near or far to production center ' } 1 \text { ' if } \\
\text { fare ' } 0 \text { ' otherwise. }\end{array}$ & $\begin{array}{l}\text { Negative } \\
(-)\end{array}$ \\
\hline Stove Design (stodes) & $\begin{array}{l}\text { Stove design is a dummy refers to whether the stove is suitable or not. A } \\
\text { value of ' } 1 \text { ' will be assigned for comfortable design ' } 0 \text { ' for others. }\end{array}$ & Positive $(+)$ \\
\hline $\begin{array}{l}\text { Early adopter neighbors } \\
\text { (eanghbo) }\end{array}$ & $\begin{array}{l}\text { A dummy variable refers to early adopt } \mathrm{HHs} \text { value } 1 \text { for early adopters } \\
0 \text { otherwise }\end{array}$ & Positive $(+)$ \\
\hline Extension worker & A dummy variable value 1 for exist 0 otherwise & Positive $(+)$ \\
\hline \multirow{2}{*}{$\begin{array}{l}\text { Household Income } \\
\text { (Gender ) }\end{array}$} & A continuous variable measured in ETH. birr & Positive $(+)$ \\
\hline & A dummy that reflects households head 1 female 0 other wise & Negative $(-)$ \\
\hline
\end{tabular}

Source: own completion (2018) 


\section{Model Specification}

The research was used logit regression model, the rural households would decide to adopt improved stove or use traditional cook stove.

$$
Y i=\left\{\begin{array}{c}
1 \text { if houshold adopts improved stove } \\
0 \text { otherwises }
\end{array}\right.
$$

Here the dependent variable is dichotomous, taking 0 or 1 values, there is a need of a probability model that has these two features $(1)$ as $\mathrm{Xi}$ increases, $\mathrm{Pi}=\mathrm{E}(\mathrm{Y}=1 \mid \mathrm{Xi})$ increases but never steps outside the $[0,1]$ interval, and (2) the relationship between $\mathrm{Pi}$ and $\mathrm{Xi}$ is non-linear thus, one can easily use cumulative distribution function (Gujarati, 2004). Both Logistic and probit regression models satisfy the above two conditions. But, even though there is no base statistical theory for preferring one over the other, there are two practical advantages of the logit model than probit model The first one is its simplicity: second its interpretability the inverse linearizing transformation for the logit model is directly interpretable as log-odds, while the inverse transformation for probit does not have a direct interpretation. By taking in to consideration these advantages, the researcher preferred to use binary logistic regression model to predict the effects of independents variables on the dependent variable.

Therefore, the dependent variable is dichotomous, i.e. to adopt or not to adopt: thus, the dependent variable $\mathrm{Yi}=$ 1 if the household adopt the stove, and $\mathrm{Yi}=0$ if the household do not adopt. To adopt or not to adopt in relation to independent variables can be depicted in linear probability as follow

$$
Y i=\beta 0+X i \beta+\varepsilon i
$$

This is the usual linear regression model, the drawback of this model are $\varepsilon i$ only two values

If $\mathrm{Yi}=1$ then $\varepsilon i=1-\mathrm{Xi} \beta$ (with prob. $\mathrm{Pi}$ )

If $\mathrm{Yi}=0$ then $\varepsilon i=-\mathrm{Xi} \beta$ (with prob. $1-\mathrm{Xi} \beta$ )

Here, $\varepsilon i$ is not normally distributed but rather has a discrete (binary) probability distribution.

Therefore, the expectation mean of ci conditional on the exogenous variables Xi from the above.

$$
\begin{aligned}
& E(\varepsilon i / X i)=(1-X i \beta) P i+(-X i \beta)(1-P i) \\
& E(\varepsilon i / X i)=P i-X i \beta
\end{aligned}
$$

Setting this mean to zero as in the classical regression analysis mean:

$$
(\varepsilon i / X i)=0, P i=X i \beta
$$

The probability of an event is always a number between 0 and 1 (inclusive) so we can see that: $P i=$ $($ prob. $1 / X i)=X i \beta$

Therefore, $\varepsilon$ i follow the binary distribution, i.e ( $\varepsilon$ i is binary distribution) leads to rise logit model. The logistic distribution function is given by:

Here the response probability prob. $(\mathrm{Yi}=1)$ is evaluated as:

$$
\text { prob. }(\varepsilon i<X i \beta)=\wedge(X i \beta)=\frac{e^{X i \beta}}{1+e^{X i \beta} \ldots \ldots \ldots \ldots \ldots(* *)}
$$

$$
\begin{aligned}
& P i=\text { prob. }(Y i=1 / X i)=\text { prob. }(\varepsilon i>-X i \beta / X i) \\
& =1-\operatorname{prob} .(\varepsilon \mathrm{i}<-X i \beta / X i) \\
& =1-\wedge(-\mathrm{Xi} \beta)=1-\frac{e^{-X i \beta}}{1+e^{-e X i \beta}} \\
& P i=\frac{e^{x i \beta}}{1+e^{X i \beta}} \text {. }
\end{aligned}
$$

Similarly, the non- response probability is evaluated as:

$$
\begin{array}{r}
1-\mathrm{Pi}=\operatorname{prob}(\mathrm{Yi}=0 / \mathrm{Xi})=1-\frac{e^{x i \beta}}{1+e^{X i \beta}} \\
1-\mathrm{Pi}=\frac{1}{1+e^{X i \beta}} \ldots \ldots \ldots \ldots \ldots \ldots \ldots
\end{array}
$$

Note that the response and non- response probabilities both lie in the interval $[0,1]$ and hence, are interpretable. Therefore, for the logit model, the ratio is given by:

$$
\begin{aligned}
\frac{P i}{1-P i} & =\frac{\operatorname{prob} .(Y i=1 / X i)}{\operatorname{prob} .(Y i=0 / X i)}=\frac{\frac{e^{X i \beta}}{1+e^{X i \beta}}}{1+e^{X i \beta}} \\
\frac{P i}{1-P i} & =e^{X i \beta} \ldots \ldots \ldots \ldots \ldots \ldots \ldots \ldots \ldots
\end{aligned}
$$

$\mathrm{Pi}$ / (1-Pi) are the odds ratio in favor of adopting the stove i.e. the household will adopt the stove to the probability that it will not adopt the stove. Taking the natural logarithm of equation (6) one can obtain.

$$
\operatorname{Ln}\left[\frac{P i}{1-P i}\right]=X i \beta=\beta 0+X 1 i \beta 1+X 2 i \beta 2 \ldots \ldots .+X k i \beta k \ldots
$$

Here the log of odds ratio is linear both in $\mathrm{Xi}$ and in the parameters. Therefore, $(\beta \mathrm{o})$ stands for intercepts. While $\mathrm{X}_{\mathrm{i}}$ is the hypothesized determinants of stove adoption and $\beta \mathrm{k}$ are the parameters to be estimated. Therefore, the model employed has the following form, with the error tem: 
$\ln \left(\frac{p i}{1-p i}\right)=\beta o+\beta 1$ age $+\beta 2$ gender $+\beta 3$ marsta $+\beta 4$ famsize $+\beta 5$ litlev $+\beta 6$ sepk $+\beta 7$ sowood $+\beta 8$ price $+\beta 9$ houincom $+\beta 10$ discen $+\beta 11$ stodesin $+\varepsilon i$

Where, $X i$-independent variables, $\beta$ o-constant, $\beta i$ - regration coefficients of the independent variable (slope)

\section{Diagnostic Test}

Before the start of complete analysis, various diagnostic tests were conducted to make the data ready for regression. Any analysis should incorporate a thorough examination of logistic regression diagnostics before reaching a final decision on model adequacy (Hosmer-Lemshew 2000). Model-Fit test is one of the most useful tests for truly assessing model fit for binary logistic regression models (Gujarati, 2004). The test shows the overall goodness of the fitted model is indicated by insignificant chi- square ( $p$ - value $>0.05$ ) the model produce a significant difference between the observed and predicted probability so, the predicted model is fitted the data well in this study since the prob $>$ chi2 was found to be 0.239 which is greater than 0.05 for the model fit test.

To test the correlation between variables included in the model pair-wise correlation test was run. As general rule, multi-collinearity is a problem when the correlation result is above 0.80 and below -0.80 (Stock and Watson, 2007). The coefficients of all variables were found to be within the specified range and hence there is no issue of multi-collinearity as it ranges from (-0.5951 to 0.7074). In addition, Variance Inflation Factor (VIF) was tested. According to Wooldridge (2002), by rule of thumb, VIF value of 10 is used as a critical point to indicate serious multi-collinearity problem. And, the minimum and maximum VIF values for this test were found 3.48 and 1.08, respectively, with mean value of 1.80 . Therefore, there was no severe multi-collinearity problem.

In standard regression, the co-efficient of determination $\left(\mathrm{R}^{2}\right)$ value gives an indication of how much variation in y is explained by the independent/ explanatory variables. This cannot be calculated the exact value for logistic regression but logistic regression gives pseudo $\mathrm{R}^{2}$ values which try to measure something similar. (From a minimum value of 0 to a maximum of approximately 1) were tested. For this study pseudo $\mathrm{R}^{2}$ was found 0.735 which implies that the explanatory variables explain the dependent variable by 73.5 percent and also the constant value is 0.048 significant its implication is that there is other variables that are reaming that are explain the dependent variable.

\section{Data Analysis and Discussion}

Table: 4.1 Type and sources of energy consumption in Assosa district

\begin{tabular}{lllc}
\hline No & Type of energy & Users & Coverage in \% \\
\hline \hline 1 & Solar & 234 & $1.2 \%$ \\
2 & Electric & 670 & $3.4 \%$ \\
3 & Biomass & 16131 & $95.4 \%$ \\
\hline & Total & 19700 & $100 \%$ \\
\hline \hline
\end{tabular}

Source: Assosa District Water Energy Office Annual report, 2017
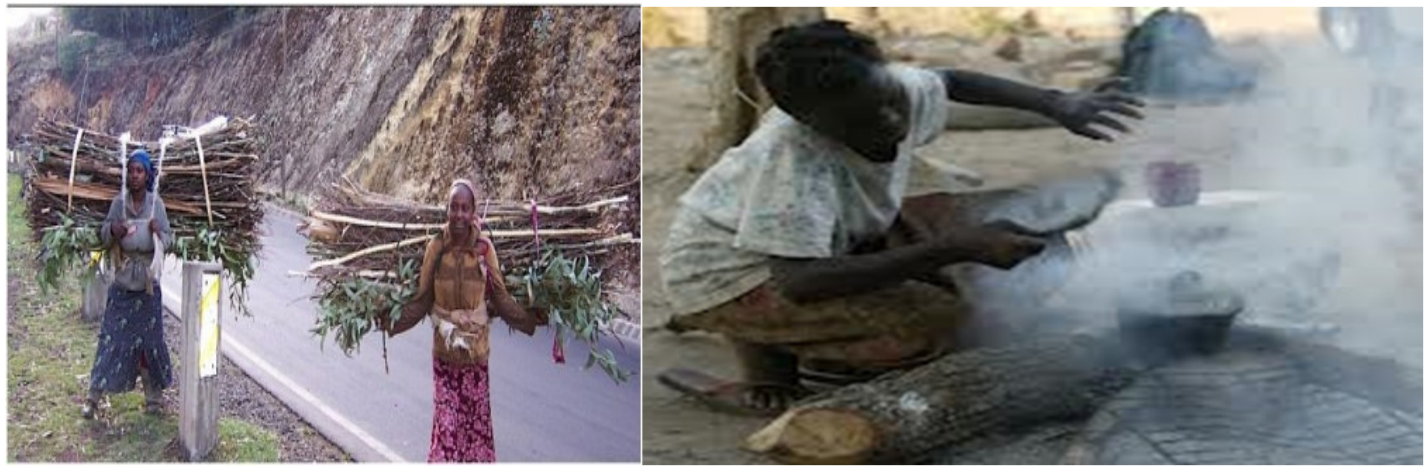

Source: Field survey photo (2018)

Food Preparation and Wood Supply Responsibilities in Rural Households

In households in which both females and males live together females are more responsible for wood collection and food preparation responsibilities the following table shows the relationship of food preparation and wood collection responsibility. 
Table:4.2 Distance travel, frequency and time spent for Biomass collection

\begin{tabular}{|c|c|c|c|c|c|c|c|}
\hline Distance in $\mathrm{kms}$ & frequ. & percent & w.c.d/week & freq. & percent & w.c.t/day & freq. \\
\hline$>5 \mathrm{kms}$ & $\overline{56}$ & 16.4 & 1 day & 24 & 7 & $<<1$ hrs & 14 \\
\hline $5-10 \mathrm{~km}$ & 85 & 24.9 & 2 day & 63 & 18.5 & $1-2 \mathrm{hrs}$ & 80 \\
\hline \multirow[t]{3}{*}{$>10 \mathrm{~km}$} & 200 & 58.7 & 3 day & 106 & 31.1 & $2-3 \mathrm{hrs}$ & 84 \\
\hline & & & 4 days & 148 & 43.4 & $3-4 \mathrm{hrs}$ & 121 \\
\hline & & & & & & $>4 \mathrm{hrs}$ & 42 \\
\hline Total & 341 & 100 & & 341 & 100 & & 341 \\
\hline
\end{tabular}

Source: Own survey $2018 \mathrm{NB}$; w.c.d/t = wood collection day / time , freq=frequency

\section{Status of Cook Stove Adoption}

According to the data collected from Assosa district water energy office, improved cook stove adoption and dissemination is poor due to different reasons, the poor implication plan is one factor of the poor adoption of the improved stove in the woreda. As per the expert and filed observation the current status of improved cook stove adoption are at low level both in terms of quantity (coverage) and quality (condition) in the study area.

We easily understand that the dissemination and distribution of improved cook stove is in minimal stage, this fact is revealed by the district energy experts regarding the development and management of improved cook stove adoption practice were slow or not developed as expected in the last five years and also not meet the minimum requirement of the GTP1 goal of the district which is at least a household use one improved cook stove at the end of the GTP. The household respondents also agree the experts' idea among the existing poor management and distribution of the improved cook stove in the study area. From the total sampling respondent households which account $85 \%$ of them Saied improved cook stove dissemination is less developed and managed compared to other social services that deliver to the community.

Table:4.3. Cook stove adoption states

\begin{tabular}{lcc}
\hline Adoption & Number of households & Percent \\
\hline \hline Adaptors & 130 & 37.8 \\
Non - Adaptors & 211 & 62.2 \\
\hline Total & 341 & 100 \\
\hline \hline
\end{tabular}

source: Own survey data (2018)

As it is observed in Table 4.3, from the total of 341 respondents $211(62.2 \%)$ were found non-adopters of improved cook stove while 130 respondents $(37.8 \%)$ are adopters. This indicates that majority of the households were found to be non-adopters.

\section{Problems of the Existing Improved Cook Stove}

Based on the data collected through appropriate instruments the most important reason for low adoption rate of improved coke stoves in the study area are poor institutional organization, low community awareness among others. The stove under dissemination is poor in quality the designs are poorly related to the feeding habits of the population in the study area. Table 4.6 below summarizes the major limitations of the current improved stoves under dissemination in the study area.

Table: 4.4. The condition of the existing cook stove

\begin{tabular}{llcc}
\hline no & Problem & Frequency & Percent (\%) \\
\hline \hline 1 & Difficult to transport & 119 & 34.9 \\
2 & Easley to crack & 127 & 37.2 \\
3 & Difficult to install & 24 & 7.0 \\
4 & Heat external part & 31 & 9.1 \\
5 & No response & 40 & 11.7 \\
\hline & Total & 341 & 100.0 \\
\hline \hline
\end{tabular}

Sources: Based on filed survey (March, 2018)

From the above table majority of the respondents respond that the stove under disseminated in the study area are un comfortable because of different reasons, i.e bulky/difficult to transport, easily cracking and heat external part are the main problems that hinder the demand of the stove respectively. So, the existing cook stove has technical problem that hinder the technology adoption by itself and they suggests the stove under distribution requires re- design to solve the existing poor quality of the stove under dissemination.

Importance of improved cook stove Adoption for Rural Household

Majority of both households with no and with accesses to modern fuel strongly agreed that use of improved stove 
benefits greater than its limitation since almost all improved stove adopter sample households recognized that it helps to very high improvement in speed of baking, reducing demand of biomass, reducing indoor air pollution, and reducing time for collection and smoke / ashes.

\section{Figure: 4.4 Comparisons the benefit of traditional and improved cook stoves}

Porridge preparation using traditional stove porridge preparation using improved stove

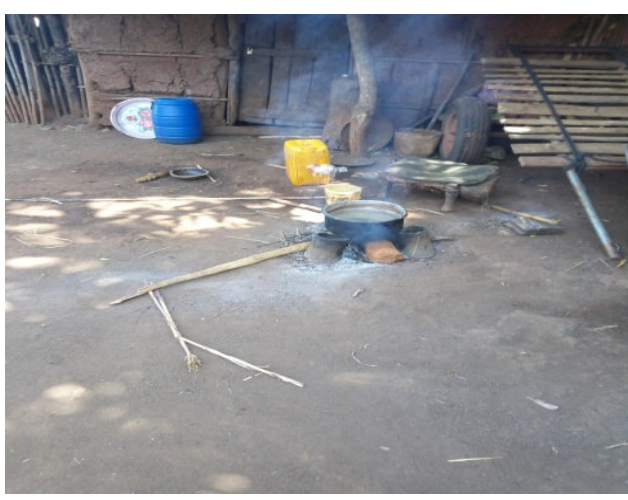

Traditional 3- stone stove injera preparation

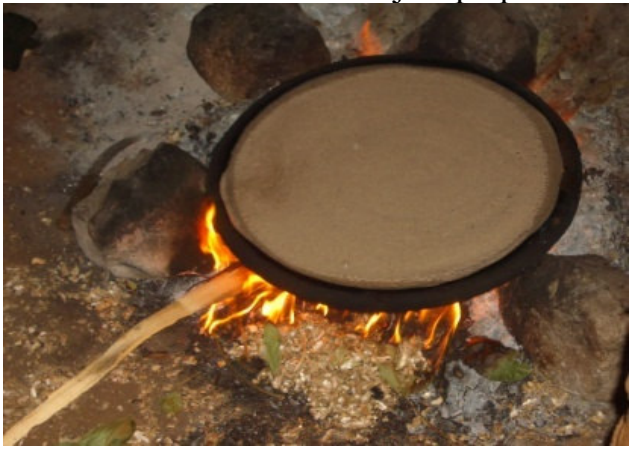

Sources: Filed photo (2018)

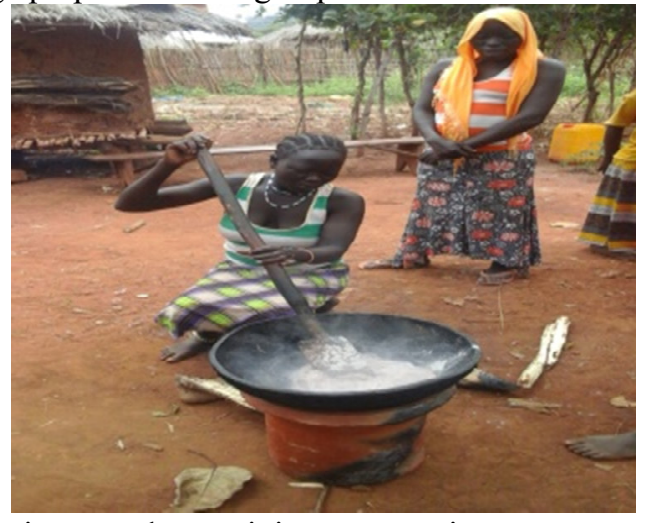

Mirt improved stove injera preparation

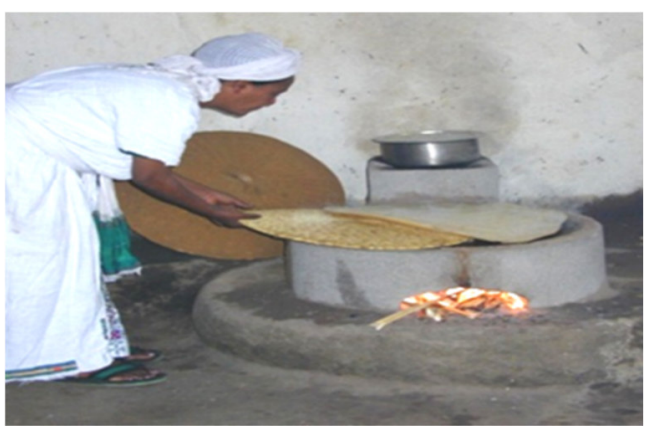

Socio-Economic and Demographic Characteristics of Respondents

The socio-economic and demographic characteristics of the respondents' show a great variation related with the differences in background characteristics of households for this study the student researcher tried to constitute different sample households with various socio-economic and demographic characteristics.

\section{Econometric Analysis and Discussion}

In the previous section, Determinants of rural households' improved cook stove adoption decision were analyzed using descriptive statistics. Further, to understand the extent to which these factors affect improved stove adoption decision binary logistic regression model was employed. The explanatory variables included and analyzed in the model are summarized as below.

Table 4.5: Summary Statistics of explanatory variables used

\begin{tabular}{lcc}
\hline Deviation & Mean & Standard \\
\hline Age of household head (in years) & 38.11 & $(11.20)$ \\
Household head is female (1=yes) & 0.129 & $(0.336)$ \\
Household head is married (1=yes) & 0.965 & $(0.185)$ \\
Household Size & 6.170 & $(2.338)$ \\
Household head literate (1=yes) & 0.393 & $(0.489)$ \\
Household has separate kitchen (1=yes) & 0.575 & $(0.551)$ \\
Household has access free wood (1=yes) & 0.601 & $(0.490)$ \\
Log of household income (in birr) & 6.553 & $(0.992)$ \\
Log of improved cook stove price & 4.293 & $(0.253)$ \\
Good stove design (1=yes) & 0.320 & $(0.467)$ \\
Log distance improved cook stove prod. (in km) & 2.22 & $(1.076)$ \\
Household with early adopters neighbor $(1=y e s)$ & 0.501 & $(0.501)$ \\
Household access extension services (1=yes) & 0.340 & $(0.474)$ \\
\hline Number of Observation s & 341 & \\
\hline
\end{tabular}

Source: Own computation using 2018 survey data 
Table 4.5 below presents results of the logistic regression model where the first column (1) depicts the likelihood (probabilities) of adopting improved cook stove in the study area. Column (2) of the same table displays the odds ratio.

Table: 4.6 logit regression result (Maximum Likelihood Estimation Result)

\begin{tabular}{|c|c|c|}
\hline VARIABLES & $\begin{array}{l}\text { (1) } \\
\text { Coefficients } \\
\text { (dummy for adoption) }\end{array}$ & $\begin{array}{l}(2) \\
\text { Odds ratio } \\
\text { (Odds ratio) }\end{array}$ \\
\hline Age of household head (in years) & $\begin{array}{l}-0.0379 \\
(0.049)\end{array}$ & $\begin{array}{c}0.963 \\
(0.039)\end{array}$ \\
\hline Household head is female ( $1=$ yes) & $\begin{array}{l}-1.111^{*} \\
(0.591)\end{array}$ & $\begin{array}{l}0.329^{*} \\
(0.237)\end{array}$ \\
\hline Household head is married ( $1=$ yes $)$ & $\begin{array}{l}-1.248 \\
(0.943)\end{array}$ & $\begin{array}{c}0.287 \\
(0.342)\end{array}$ \\
\hline Household Size & $\begin{array}{c}0.0796 \\
(0.167)\end{array}$ & $\begin{array}{c}1.082 \\
(0.164)\end{array}$ \\
\hline Household head literate ( $1=$ yes) & $\begin{array}{l}1.366 * * * \\
(0.501)\end{array}$ & $\begin{array}{r}3.920 * * * \\
(2.103)\end{array}$ \\
\hline Household has separate kitchen ( $1=$ yes) & $\begin{array}{l}-0.278 \\
(0.398)\end{array}$ & $\begin{array}{c}0.757 \\
(0.331)\end{array}$ \\
\hline Household has access free wood ( $1=$ yes $)$ & $\begin{array}{l}-0.629 \\
(0.516)\end{array}$ & $\begin{array}{c}0.532 \\
(0.289)\end{array}$ \\
\hline Log of household income & $\begin{array}{l}1.523 * * * \\
(0.447)\end{array}$ & $\begin{array}{r}4.585 * * * \\
(1.588)\end{array}$ \\
\hline Log of improved cook stove price & $\begin{array}{c}0.580 \\
(0.957)\end{array}$ & $\begin{array}{c}1.786 \\
(1.881)\end{array}$ \\
\hline Good stove design ( $1=$ yes $)$ & $\begin{array}{l}2.609 * * * \\
(0.631)\end{array}$ & $\begin{array}{r}13.580 * * * \\
(8.287)\end{array}$ \\
\hline Log distance improved cook stove production. & $\begin{array}{c}-0.851 * * * \\
(0.231)\end{array}$ & $\begin{array}{l}0.427 * * * \\
(0.108)\end{array}$ \\
\hline Household has early adopters neighbor $(1=$ yes $)$ & $\begin{array}{l}1.302 * \\
(0.667)\end{array}$ & $\begin{array}{l}3.677^{*} \\
(2.676)\end{array}$ \\
\hline Household access extension services ( $1=$ yes) & $\begin{array}{l}0.0730 \\
(0.545)\end{array}$ & $\begin{array}{c}1.076 \\
(0.582)\end{array}$ \\
\hline Constant & $\begin{array}{c}-11.15^{*} \\
(5.628)\end{array}$ & $\begin{array}{l}0.000 * \\
(0.000)\end{array}$ \\
\hline Observations & 341 & 341 \\
\hline
\end{tabular}

Robust standard errors in parentheses $\quad * * * \mathrm{p}<0.01, * * \mathrm{p}<0.05, * \mathrm{p}<0.1$

Source: Own data survey (2018)

\section{Regression Result Interpretation}

Variables that have significant explanatory power in determining the improved cook stove adoption decision are interpreted in this section. The coefficient and odd ratios of these powerful explanatory variables are interpreted.

Gender: As indicated in the above table 4.6, as it was expected the variable gender is significant at $10 \%$ level of significance. This variable has a p-value and odd ratio 0.060 and 0.329 , respectively. This implies that since, the coding gender (1) refers to female heads and the reference category gender (0) refers to male heads thus, the likelihood adopting improved cook stove is about 67.1\% (=1- 0.329) higher for female household heads as compared male households heads keeping all other covariates fixed.

This finding reveals that majority of preparation of food were done by mothers in both households with no and with access to modern fuel followed by daughters and servants. Almost fathers and boys do not have contribution of food preparation in both households with no and with modern fuel. This implies women are recognized as the primary source of biomass energy collectors as well as the emission receiver. Hence cooking food is considered as women's task and is generally conducted by women though the male helps her but staying near the fire is always women and the children. The result of this study is consistent with empirical studies of Warkaw (2015), Damte and Koch (2011) that found female headed households adopt improved stove more quickly than male headed household.

Literacy level: woman's level of literacy was found significant determinant factor in that affect positively rural household's improved cook stove adoption decision. Household literacy level significantly affects the probability 
of improved cook stove adoption with p-value and odd ratio of 0.006 and 3.920, respectively. Since, coding literate (1) refers to literate household heads and the reference category illiterate( 0$)$ is illiterate household heads, the odd ratio is greater than one, the implication is literate household head are 3.920 times more likely adopt improved cook stove as compared illiterate household keeping all other covariant constant.

This finding also confirms household energy stacking theory that asserts in addition to economic factors, there are other factors (for instance, literacy level) which affect a household's fuel or technology switching, adoption decision. Moreover, the finding of this study is similar to previous works (Puzzolo et al., 2013; Damte \& Koch, 2011; Inayat, 2011; Tigabu, 2014) that found educated household head are more aware of the environment and health effect of using biomass fuel so, literacy level is a significant positive factor in determining a household's improved cook stoves adoption decision.

Household income: As Table 4.6 shows, household income was found positive significant determinant factor that affects improved cook stove adoption decision with p-value of 0.001 and odd ratio 4.585 which is significant at $1 \%$ level of significance. This implies that as household income increase by one birr the probability of improved cook stove adoption increase by 4.585 percent keeping other covariates constant.

As it was discussed in descriptive analysis part, this study supported household energy transition theory that argues fuel choice is determined by income of the household when income increases household start to take clear modern fuel and new cooking practice. In line with this the energy ladder hypothesis argues that increase in income will change households demand for sources of energy. The finding of this study is similar to previous works (Puzzolo, 2013; Damte \& Koch, 2011), Morbabazi (2016) and Menon ad Thandapani (2011) found that household income has significant positive effect on a household's improved cook stoves adoption decision as household income increase the improved cook stove adoption increased.

Distance from production center: As table 4.15 above shows that the distance from household home to improved cook stove production center has a negative effect on the adoption of improved stove decision of households at statistically significance level of $1 \%$ with p-value of 0.000 and odd ratio 0.427 respectively. This implies that as household distance from stove production center increase by one kilometer, the probability of improved cook stove adoption decrease $(1-0.427=0.573)$ by 57.3 percent keeping other covariate constant.

This study is similar to previous works of Kersten et al., (2015); Inayat, (2011); Adkins, (2010); Makori, (2016) that found centralization of stove production at the center has significant negative effect on rural households improved cook stove adoption. This study also came up with similar findings of Petter (2015), Makori (2016) and Adkins et al., (2010) found that if the cook stove production center/site far from the household resident, accessibility of improved cook stove are not easy and take more time to adopt and add cost of the stove and the probability of broken is high due bad road in rural areas. So, probability of adoption decreases as distance from center increase.

Early adopter neighbors: As it was expected the existences of early adopter neighbors were a positive significant factor that determines a households' improved cook stove adoption decision. This variable has p-value and odd ratio 0.051 and 3.677 respectively. The odd ratio is greater than one, the implication is that household who have early adopter neighbors are 3.677 times more likely adopt as compared to household don't have early adopter neighbors keeping other covariant fixed. This finding confirms household energy defusing theory which asserts that early adopters create quake connection of the new technology with others and this theory illustrates that how face to face communication is more influential to create a network among the households. The result of the study also similar to the work of Puzzolo et al., (2013), Gebreegziabher et al., (2010), Shannon (2011) and Tigabu (2014) that found early adopter neighbor as one factor that positively determines the improved stove adoption decision.

Stove Design: As it was expected stove design was a positive significant factor that determines a households' improved cook stove adoption decision. This variable has p-value and odd ratio 0.000 and 13.580 respectively. The reference category stove design $(0)$ refers to one who is not adopt improved cook stove and the odd ratio 13.580 is greater than one. The implication is that household comfortable stove designs with their feeding system are 13.580 times more likely adopt improved cook stove as compared to households stove design not comfortable with their feeding system holding all other variables constant.

This study came up with similar findings of Puzzolo et al., (2013), Gebreegziabher et al., (2010) and Warkaw (2015) that found develop favorable stove design with the feeding culture of the community as one determinant factor that affects improved cook stoves adoption decision. The result of the study also similar to the work of Innayt (2011), Adkins et al., (2010) and Makori (2016) that found stove should develop based on the food preparation approach of the community are increase the demand of the stove so, comfortable stove design is positively determine stove adoption decision.

\section{Interview Result Discussions}

Almost all sub district leaders and development workers recognized that biomass source of energy such as wood, leaves and crop residues, and also charcoal are found the main source of energy consumption in the study area used for their food preparation. Furthermore, the respondents identified that kerosene are the main source of energy 
used for the purpose of lighting by households with no access to modern electricity.

Based on the major sources of energy consumption the respondents recognized that the problem of deforestation, cutting of big trees leads to high depletion of the forest resources in Assosa district. Additionally, the respondents are also identified the problem of smoke and ashes leads source of indoor air pollution furthermore; women spend a lot of time for collection of fuel that could participate in productive activities.

Both of sub district leaders and development workers are strongly agree that government collaboration with development partner non-governmental organization currently plans to change the present energy consumption patterns based on improved cook stove distribution to rural households but the distribution is at the infant stage.

\section{District and Regional Key Informants}

Key informants also agreed that firewood and crop residues are found the main sources of household energy consumption for purposes of cooking and baking their food while kerosene, electricity and solar are used for purpose of lighting. The major ground to use these is easily accessible, cultural preference and convenience source of energy consumptions. And based on their experience they observed that enhancement towards efficient utilization of energy consumption through improved stove adoption is the best mitigation mechanism for the household health and environmental protection.

Regarding the importance of improved cook stove for the rural communities the key respondents said that it has a remarkable and multiple benefit for users for example in the region Gonziye and lakech stove type are distributed. So, scientifically those improved cook stoves have much importance for the community. Both are save more than 50\% fire wood during food preparation, produce fewer smocks, 18-25 efficient, clear and comfortable, improve heat transfer by $60 \%$ to the pot, reduce fire incidence, it helps to create job opportunity and additional income for rural residents and fast comparing with traditional three stone cooking approach.

\section{Conclusion}

The finding reveals that majority of households energy consumption, depends on fire wood followed by crop residual leafs and coal which cover $80.7 \%, 17.8 \%$, and $1.5 \%$ respectively while kerosene, solar and electricity are lowest energy consumption in rural district for the purpose of light. This heavily dependency of biomass (wood, crop residuals and leafs) as sources of energy may aggravate, deforestation and lose of soil fertility which in turn environmental degradation, human health problem and farm land productivity reduction.

Improvement in resource-use efficiency through technological alternatives like biogas, wind power, solar energy and improved stove technology is vital however still application of technological alternative energy saving production and the district is in infant stage. The economic, social, environmental and health benefits from these stoves have always outweighed the costs of the stoves. The slow rate of adoption of such stoves is common. Furthermore, survey result shows that only 38.1 per cent of the households adopt improved cook stove and more advantages in terms of high improvement in speed of baking, reduce biomass collection time and reduce smoke as compared to non-adopters.

Among the improved cook stove adoption factors, gender of the household head is found to be negative and significant to affect adoption i.e. female headed households are more likely to adopt energy saving cook stove compared to male headed households. Regarding education only 26.8 per cent of literate households found to be not engage on improved cook stove adoption, while 73.2 per cent of the literate households adopt improved cook stove, this difference is highly significant implying that literate household heads have more likelihood to access modern improved cook stove than their counterpart households.

Adoption of improve cook stove is positively and significantly affected by economic status and positively related to neighborhood effect that is improved stove adopter households have 71.9 per cent early adopter neighbors while non-adopter households 28.1 per cent as well as a stove design which fits the cultural food preparation practice of a community is found to be an important and significant factor for adoption.

\section{Recommendations}

Heavy dependence and inefficient utilization of biomass energy sources have contributed to forest depletion, indoor air pollution and productivity reduction in the district among others. To overcome these challenges, rural development planners and policy makers should encouraged rural households to adopt improved cook stove.

To fill the information on alternative technologies gaps different strategies should be planned to introduce and disseminate the alternative technologies, or at least public awareness creation effort should be strengthen about the benefits of energy saving device and technologies via religious places, meeting places, market places, improved cook stove dissemination initiations, experience share with early adopters, posters, and radio and TV advertisements is vital. The government and other development partners should be assist producers through different mechanisms such as information delivery, design improvement training, technical and material support are vital to minimize the challenges of producers.

Motivate women to use improved cook stove sustainably for their livelihood and to be came active participant 
in different social associations and activities for instance Idir, ekub, development associations and women selfhelp groups to engage in the production, distribution, and sale of improved cook stove is vital and government should fully organize different potential stove producers with considerable provision of different services such as credit access, training, market linkage and material support to increase availability of improved cook stove at affordable price and decentralize improved cook stove production site and management services down to the grass roots level so as to make potential users own the improved stove.

Technical faults during and post implementation and methods to monitor and quantify the performance of the improved stoves needs to be care as well as technology improvement should consider the cooking methods, the food-menu, and the user behavior.

\section{References}

Adkins, E., Tyler, E., Wang, J., Siriri, D. \& Modi, V. (2010), Field testing and survey Evaluations of household biomass cook stoves in rural sub-Saharan Africa. Energy for Sustainable Development pp. 172-185

Amogne (2014), Factors Affecting the Adoption of Fuel Efficient Stoves among Rural Households in Borena Woreda, Wollo University, Ethiopia pp, 141-154

Anthony and chikamso, (2017), Assessing the use and determinants of households Adoption Of improved cook stove. Asian journal of environment and economy article number, AJEC 3528, university of Nigeria

Beyene, A. D., \& Koch, S. F. (2013), Clean fuel-saving technology adoption in urban Ethiopia. Energy Economics, 36, 605-613. $\quad$ Retrieved April 28 , 2014 from http://www.sciencedirect.com/science/article/pii/S0140988312002770

Damte, A. and Koch, F., S. (2011). Clean fuel saving technology adoption in urban Ethiopia, working paper series 2011-09, Department of Economics University of Pretoria, South Africa

Gebreegziabher, Z., Mekonnen, A., Kassie, M. \& Köhlin G. (2012) .Urban energy Transition and Technology adoption: The case of Tigrai, Northern Ethiopia. Discussion paper EfD 10(22). Environment for Development (EfD) Initiative, and Resources for the Future (RFF), Washington, DC

Gifford, M. (2010).A global review of cook stove programs

Grace A. (2014), Determinants of energy saving cook stove adoption in rural households Of Kisumu north location, University of Nairobi, Kenya

Gujarati, D. N. (2004) Basic Econometrics (4th Ed.), New Work, NY: The McGraw-Hill Companies

Inayat, J. (2011) what makes people adopt improved cook stoves? Empirical evidence from Rural North West Pakistan, Working Paper 012, the Governance of Clean Development Working Paper Series, School of International Development, University of East Anglia UK

Hammond, B. A. (2007), Challenges to increasing access to modern energy services in Africa. Forum of Energy Ministers of Africa (FEMA) Conference on Energy Security and Sustainability 28-30 March 2007 Maputo, Mozambique. Retrieve From: http://www.fema-africa.net.

Heimann, (2007) Renewable energy in Ethiopia for a sustainable development Addis Ababa Retrieve from: www.stefanheimann.eu

Hosmer.D.W. and Lemshow.S, (2000) Applied Logistic Regression second Edition New York, USA, John Wiley and Sons

Hude, (2014) improved cook stove for rural India: issues and recommendation, Institution of Technology, Mumbai, India

Kothari, C.R. (2004). Research Methodology Methods and Techniques, New Delhi, India New Age international Limited publisher

Makori, M. (2016) Drivers of utilization of improved energy saving cook stoves projects a case of Bomet County in Kenya, Jomo Kenya University of Agriculture and Technology (JKUAT), Kenya Vol. 3, Iss. 1 (14), pp 299-327

Masera, O., Saatkamp, D. \& Kamme, M. (2000). From linear fuel switching to multiple Cooking strategies: A critique and alternative to the energy ladder model. World Development Vol. 28, No. 12, Pp. 2083-2103.

Menon, S. \& Thandapani, S. (2011). Understanding the adoption dynamics of new Products among people living in rural India .Working paper (2011-2012), Centre for Development Finance Institute for Financial Management Research

Mobabazi.M. Ruti.R. \& Jaya.S.(2016), Determinants of Adoption of Biomass Stove in Rural Households for muhazi sector in Rawamagana district, Jomokeniyata University of Agricaltural \& technology, Kigali , Rwanda National clean cook stove program in Ethiopia (NCCCPE, 2011) Road map

Puzzolo, E., Stanistreet, D., Pope, D., Bruce, N. \& Rehfuess, E. (2013), Factors Influencing the large-scale uptake by households of cleaner and more efficient household energy technologies: Systematic review

Sameer, (2011) Household Cook stoves, Environment, Health, and Climate Change A new Look at an old problem, World Bank Washington.

Smith, K. R., Bruce, N., Balakrishnan, K., Adair-Rohani, H., Balmes, J., Chafe, Z., \& Rehfuess, E. (2014), Millions 
dead: how do we know and what does it mean? Methods used in the comparative risk assessment of household air pollution. Annual review of public health, 35, 185-206

Shanko, M., T. Abebe, and H. Lakew, (2009), 'A report on Mirt biomass injera Stove Market Penetration and sustainability study in Amhara, Oromiya and Tigray National Regional States, GTZ Sun Energy.

Shannon H. (2014), Clean Cooking: The Value of Clean Cook stoves in Ethiopia Journal of Environmental, resources and economics at Colby, issue 01, volume 1

Stock, J. \& Watson, M. (2007) Introduction to econometrics (2nd ed.). Botson: Pearson Addison Wesley

Tigabu, (2014), Factors Affecting Adoption of Improved Cook stoves in Rural Areas Evidence from 'Mirt' Injera Baking Stove the Survey of Dembecha Woreda, Amhara Regional State Ethiopia.

Warkaw L. (2011), Factors Affecting the Adoption of Fuel Efficient Stoves among Rural Households in Borena Woreda: North central Ethiopia. International Journal of Energy Science (IJES) Volume 4 Issue 5 pp, 141154

World Bank (2010) Improved Cook stoves and Better Health in Bangladesh: Lessons from Household Energy and Sanitation Programs, Washington, USA

World vision, (2016) Easing women's life with energy efficiency cook stove, world Vision, Ethiopia.

Zenebe, (2006) Contribution of improved cook stove in land degradation in Ethiopia, Wageningen, University, Netherlan

Kersten, F., Engelhart, P., Ploigt, H.C., Stekolnikov, A., Lindner, T., Stenzel, F., Bartzsch, M., Szpeth, A., Petter, K., Heitmann, J. and Mueller, J.W., 2015. Degradation of multicrystalline silicon solar cells and modules after illumination at elevated temperature. Solar Energy Materials and Solar Cells, 142, pp.83-86.

Woldu, A.R. and Tsigie, Y.A., 2015. Optimization of hydrolysis for reduced sugar determination from avocado seed wastes. American Journal of Environment Energy and Power Research, 3, pp.1-10.

Wooldrige, J.M., 2002. Econometric Analysis of Cross Section and Panel Data. MIT Press, Cambridge, MA. 